Vol. 2, No. 2, 2019

\author{
A. M. Ludyn, V. V. Reutskyy, V. V. Reutskyy \\ Lviv Polytechnic National University, \\ Department of Technology of Organic Product \\ anatolii.m.ludyn@1pnu.ua
}

\title{
CREATING THE BASIS OF NON-EXHAUSTIVE TECHNOLOGY OF CYCLOHEXAN OXIDATION
}

https://doi.org/10.23939/ctas2019.02.091

The bases for complex processing and creation of non-waste technology of oxidation process of cyclohexane are proposed. The methods of using by-products of the oxidation process of cyclohexane - alcohol fraction and acid mixture are considered. The method of using the alcohol fraction as an effective additive to diesel fuels is studied. It was investigated that alcoholic additive improves the technological and operational properties of diesel fuels. The method of using a mixture of acids obtained in the process of oxidation of cyclohexane for the esterification of them with butyl alcohol and the preparation of a valuable ester, dibutyl adipinate, was studied.

Key words: oxidation, cyclohexane, alcohol fraction, adipic acid, esterification, ester, diesel fuel.

\section{Introduction}

As for today one of the most important issue of the Ukrainian industry is complex processing of byproducts and waste-free technologies that reduce material consumption of the product, its cost, and that significantly reduce the level of pollution of air, water, soil.

The main disadvantage of industrial oxidation processes of hydrocarbons is a free radical mechanism that requires complex conditions (temperature and pressure) and causes low selectivity during deeper oxidation. Among industrial processes oxidation of cyclohexane $(\mathrm{CH})$ - intermediate product in the production of polyamide fibers - plays a significant role [3]. The peculiarity of the process is the formation of a large number of by-products, most important of which are alcohol fraction and acids, mainly adipic acid, that do not find a qualified use due to the complications of their obtaining and purification. These products are mostly burned, that leads to an increase in production cost factors. In addition, low conversion rates of raw materials lead to high energy consumption in the production, which is due to the recycling of unreacted raw materials.

Taking all of mentioned into account, it is therefore important to focus research on the finding of new improvements of the known methods of use of the by-products. The use of the alcohol fraction as an effective additive to fuels [10-12] and a mixture of acids as raw materials for their esterification with alcohol are perspective.

It is known [1] that one of the directions of disposal of alcohol waste can be to add them to the fuel of the carburetor engines. It was investigated that the addition of alcohol waste to gasoline, facilitates their fractional composition, which leads to improved engine performance in various regimes; with the temperature of the beginning of boiling rises, which prevents premature evaporation of fuel in the fuel system of the engine. It also improves the character of combustion of fuels, increases detonation resistance of fuels, improves their operational properties.

One of the methods of use of acids is to obtain acid esters by their esterification with alcohol [2, 4, $5-9,13]$. Subsequently, the esters obtained can be used as plasticizers for polymers. In the case of esterification with lower alcohols, the esters obtained can be separated at boiling point and used as raw material for the allocation of individual acids.

\section{The aim of the study}

Study of methods for the use of by-products of the oxidation process of cyclohexane - alcohol fraction and acid mixture, for a comprehensive recycling and creation of zero waste technologies of this process. 


\section{Materials and methods of the research}

To study the method of use of the alcohol fraction, the taken alcohol fraction (AF) was - the waste of the oxidation process of the production of adipic acid from PJSC "Rivne Azot" and the direct fission fraction of diesel fuel after atmospheric distillation. We have prepared mixtures of diesel fuel samples with $\mathrm{AF}$ additives in the following bulk proportions:

1. diesel $(100 \%)+\mathrm{AF}(0 \%)$

2. diesel $(95 \%)+\operatorname{AF}(5 \%)$,

3. diesel $(92 \%)+$ AF $(8 \%)$,

4. diesel $(90 \%)+$ AF $(10 \%)$,

5. diesel $(89 \%)+$ AF $(11 \%)$,

6. diesel $(88 \%)+$ AF $(12 \%)$,

7. diesel $(87 \%)+$ AF $(13 \%)$

8. diesel $(86 \%)+$ AF $(14 \%)$,

9. diesel $(85 \%)+\mathrm{AF}(15 \%)$

10. diesel $(82 \%)+\operatorname{AF}(18 \%)$,

11. diesel $(80 \%)+$ AF $(20 \%)$.

For the created mixtures density was found by $\rho^{15}$ pycnometric method, kinematic viscosity $v$ by capillary viscometer. After that, the distillation of diesel fuel and prepared mixtures was performed, during which their fractional composition was determined, namely: the temperature of the beginning of boiling, the boiling point of $10 \%$, and $50 \%$ of the points. The fractional formulations obtained were analyzed and cetane indices were determined for the analyzed samples.
For diesel fuels, the main parameters that characterize the period of ignition delay from compression of the fuel-air mixture are the cetane number and the cetane index (CI) - an indicator used in European standards.

The determination of the CI was carried out according to CT CEB 5871-87 method of determining the density of diesel fuel at $15{ }^{\circ} \mathrm{C}$ and the average boiling point of the $50 \%$ (by volume) of its amount. The cetane index was calculated by the formula:

$$
\begin{gathered}
C I=454.74-1641.416 \cdot \rho+774.74 \cdot \rho 2- \\
-0.554 \cdot t+97.803 \cdot(\operatorname{lgt}) 2,
\end{gathered}
$$

where $\rho^{15}$ - density of diesel at $15^{\circ} \mathrm{C}, \mathrm{g} / \mathrm{sm}^{3} ; \mathrm{t}-$ boiling temperature of $50 \%$ (volume) analyzed mixture, ${ }^{\circ} \mathrm{C}$.

To study the method of use of a mixture of acids, mainly adipic acid, was used oxidate obtained by oxidation of $\mathrm{CH}$ in the presence of a catalytic system [NC-CEE] (NC: $\mathrm{CEE}=1: 1$ ). The composition of oxidation products containing this oxidate is given below (Table 1).

The obtained acids from the mixture of the remaining products were separated by washing with water. The resulting aqueous solution of organic acids was concentrated by evaporation of water. The composition of the resulting acid solution is given in Table. 2 .

Table 1

Composition of products obtained by oxidation of cyclohexane $(\mathrm{CH})$ in the presence of binary catalytic system NC-CEE. $k, \%-11,96$

\begin{tabular}{|c|c|c|c|c|}
\hline $\begin{array}{c}\mathrm{C}(\mathrm{HPCH}), \\
\mathrm{mol} / 1\end{array}$ & $\begin{array}{c}\mathrm{C}(\mathrm{AC}), \\
\mathrm{mol} / 1\end{array}$ & $\begin{array}{c}\mathrm{C}(\mathrm{DCA}), \\
\mathrm{mol} / 1\end{array}$ & $\begin{array}{c}\mathrm{C}(\mathrm{COL}), \\
\mathrm{mol} / 1\end{array}$ & $\begin{array}{c}\mathrm{C}(\mathrm{CON}), \\
\mathrm{mol} / 1\end{array}$ \\
\hline 0.026 & 0.433 & 0.090 & 0.177 & 0.225 \\
\hline $\begin{array}{c}\mathrm{S}(\mathrm{HPCH}), \\
\%\end{array}$ & $\begin{array}{c}\mathrm{S}(\mathrm{AC}), \\
\%\end{array}$ & $\begin{array}{c}\mathrm{S}(\mathrm{DCA}), \\
\%\end{array}$ & $\mathrm{~S}(\mathrm{COL}), \%$ & $\mathrm{~S}(\mathrm{CON}), \%$ \\
\hline 0.24 & 39.15 & 8.09 & 15.98 & 20.37 \\
\hline
\end{tabular}

Table 2

Composition of water solution of acids

\begin{tabular}{|c|c|c|c|c|}
\hline $\begin{array}{c}\mathrm{C}(\mathrm{AC}), \\
\mathrm{mol} / \mathrm{l}\end{array}$ & $\begin{array}{c}\mathrm{C}(\mathrm{HPCH}), \\
\mathrm{mol} / \mathrm{l}\end{array}$ & $\begin{array}{c}\mathrm{C}(\mathrm{DCA}), \\
\mathrm{mol} / \mathrm{l}\end{array}$ & $\begin{array}{c}\mathrm{C}(\mathrm{COL}), \\
\mathrm{mol} / \mathrm{l}\end{array}$ & $\mathrm{C}(\mathrm{CON}), \mathrm{mol} / \mathrm{l}$ \\
\hline 0.476 & 0.001 & 0.023 & 0.009 & 0.014 \\
\hline
\end{tabular}

\section{Results and discussion}

The results of experimental data and calculations for pure diesel fuel and its mixtures with additives of alcohol fraction (AF) are shown in Table 3.
According to the data of the table, the graphs of the dependence of CI, kinematic viscosity, boiling start temperatures and boiling of $10 \%$ and $50 \%$ of the points from the concentration of alcohol fraction 
in diesel fuel were constructed. To evaluate the operational properties of the prepared fuel mixtures, their fractional composition was analyzed.

According to the results of the analysis, the following conclusions can be drawn. Additives of alcohol fraction increase the cetane index of diesel fuel in a definite interval, which is observed at a concentration of SF from $10 \%$ to $13 \%$, which is visible on the curve of Fig. 1.

This positively affects the characteristics of self-combustion, because faster is the pre-oxidation of fuel in the combustion chamber, and the faster the mixture lights up and the engine starts. AF additives above $15 \%$ lower the cetane index of diesel fuel.

With the addition of the alcohol fraction, the temperature of the boiling start decreases, which characterizes the starting properties of the fuel (Fig. 2). With the decrease of this temperature, the amount of easily evaporating substances increases, which makes it easier and at lower ambient temperature to start the engine.

Similarly, with addition of alcohol fraction, the boiling temperature of $10 \%$ of fuel is lowered, which also improves engine start-up properties. Especially this dependence is manifested when the concentration of SF is reached $-10 \%$ (Fig. 3).

\section{Table 3}

Results of research for the diesel and its mixture with AF

\begin{tabular}{|c|c|c|c|c|c|c|}
\hline $\begin{array}{c}\text { Dies. } \\
\% \mathrm{v}\end{array}$ & $\begin{array}{c}\mathrm{AF}, \% \\
\text { vol }\end{array}$ & $\begin{array}{c}v 20, \\
\mathrm{cC} \text { T }\end{array}$ & $\begin{array}{c}\rho_{4}{ }^{15}, \\
\mathrm{~kg} / \mathrm{M}^{3}\end{array}$ & $\begin{array}{c}\mathrm{T}_{\text {boil }} \\
{ }^{\circ} \mathrm{C}\end{array}$ & $\begin{array}{c}\mathrm{t}_{10}, \\
{ }^{\circ} \mathrm{C}\end{array}$ & $\begin{array}{c}\mathrm{t}_{50}, \\
{ }^{\circ} \mathrm{C}\end{array}$ \\
\hline 100 & - & 4.07 & 835.75 & 174 & 214 & 278 \\
\hline 95 & 5 & 4.01 & 833.47 & 140 & 202 & 273 \\
\hline 92 & 8 & 3.74 & 833.31 & 136 & 170 & 273 \\
\hline 90 & 10 & 3.72 & 832.95 & 134 & 152 & 272 \\
\hline 89 & 11 & 3.70 & 830.24 & 134 & 151 & 271 \\
\hline 82 & 12 & 3.68 & 825.50 & 134 & 150 & 271 \\
\hline 87 & 13 & 3.65 & 828.34 & 135 & 150 & 268 \\
\hline 86 & 14 & 3.78 & 830.74 & 133 & 152 & 263 \\
\hline 85 & 15 & 3.91 & 831.40 & 132 & 150 & 262 \\
\hline 82 & 18 & 3.96 & 831.91 & 130 & 148 & 255 \\
\hline 80 & 20 & 4.01 & 832.34 & 128 & 148 & 250 \\
\hline
\end{tabular}

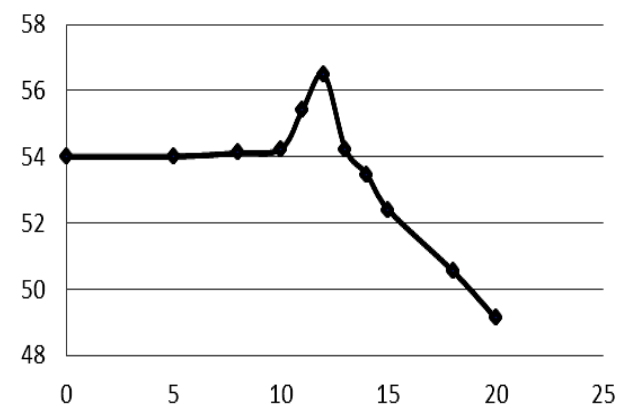

Fig. 1. Dependence of CI from concentration of $A F(\%)$ in diesel

Fig. 3. Dependence of $T_{\text {boil }} \cdot 10 \%$ mixture from concentration of $A F(\%)$ in diesel

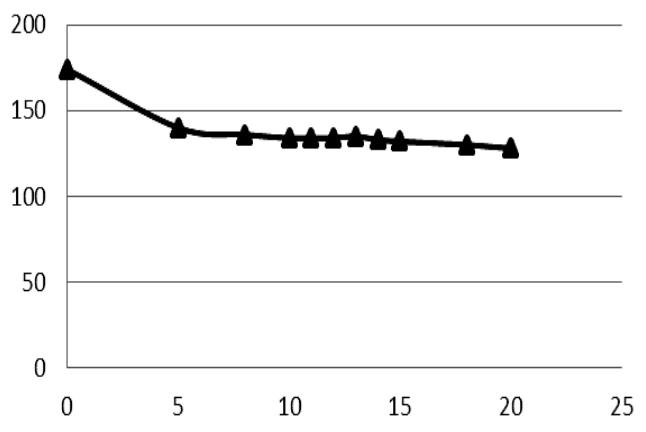

Fig. 2. Dependence of $T_{\text {boil }}$.

Of mixture from concentration of $A F(\%)$ in diesel

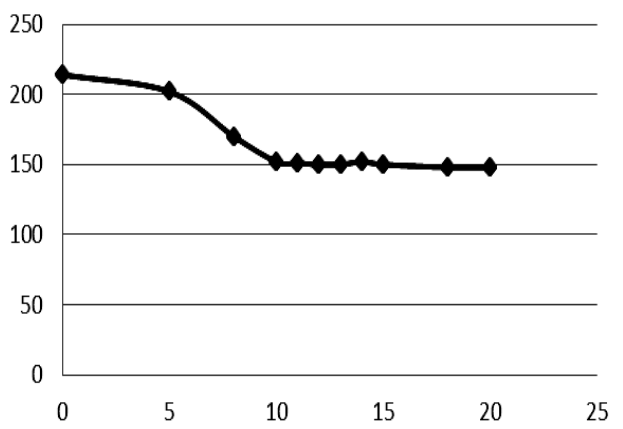




\section{А. М. Лудин, В. В. Реутський, В. В. Реутський}

From Fig. 4 it is evident that with the addition of alcohol fraction the temperature of boiling up to $50 \%$ of the amount of fuel decreases, and until the concentration of $\mathrm{AF}=12 \%$ is reached, this dependence is manifested by a smooth decrease, and even higher concentration of alcohol fraction of $12 \%$ begins a sharp decrease of $\mathrm{T}_{50}$. This has a positive effect on diesel engine, because it facilitates its evaporation and thus provides the possibility of smoother and more stable engine operation, significantly improves its maneuverability, as well as significantly reduces fuel consumption.

The viscosity of diesel fuel largely determines the operation of diesel equipment diesel engine. Figure 5 shows the effect of SF additives on the viscosity of the fuel mixture. Additives of alcohol fraction reduce the viscosity of diesel fuel in a definite interval, which is observed at a concentration of $\mathrm{AF}$ from $5 \%$ to $18 \%$ with a minimum of $12-13 \%$. Reducing the viscosity of the fuel leads to easier fuel spraying, which ensures the most complete and rapid evaporation of it. The fineness of the sawing is estimated by the size of the droplets, which provide the most complete and fast evaporation and should be within the limits of 5-40 microns. The less viscous fuel is better ignited and burned, which leads to a reduction in its cost and exhaust smoke. It is also positive that the viscosity of the mixtures analyzed does not decrease less than 3 cSt, because low-fueled fuel during operation increases the wear of parts of the fuel pump.

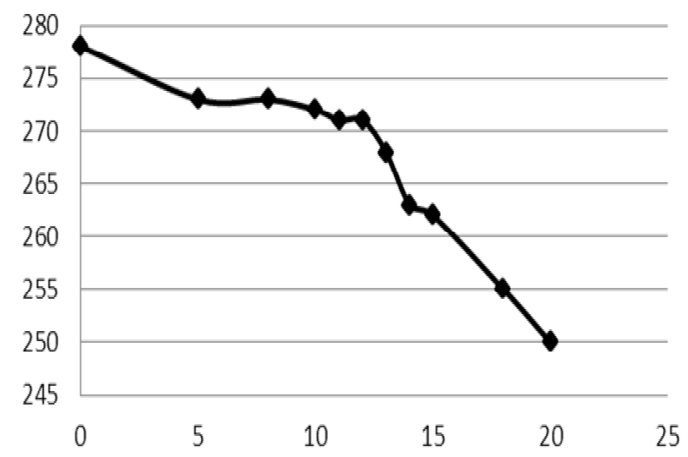

Fig. 4. Dependence of $T_{\text {boil. }} .50 \%$ mixture from concentration of $A F(\%)$ in diesel

Addition of a withdrawal of the process of oxidation of cyclohexane - alcohol fraction - to diesel fuels positively affects their fractional composition, which leads to improvement of engine operation in various regimes; improves its starting properties, improves engine maneuverability, facilitates spraying and reduces fuel consumption and its propensity to form steam-air cocks in the engine power supply. Additives of alcohol fraction increase the cetane index - a characteristic that is used in European standards. The optimum concentration of the alcohol fraction additive is in the range of 10 to $13 \%$ by volume.

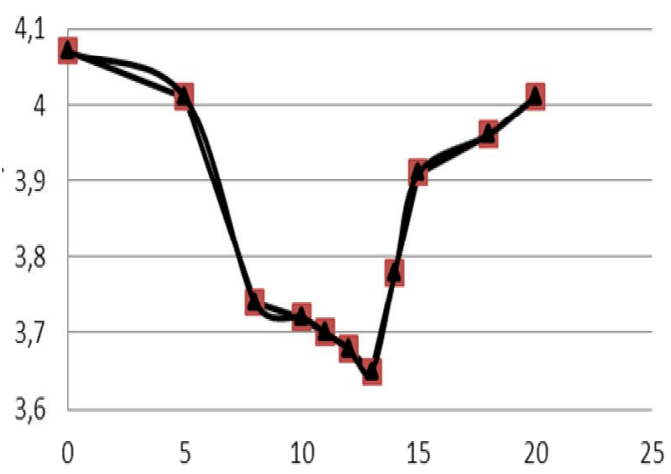

Fig. 5. Dependence of viscosity from concentration of $A F(\%)$ in diesel

The resulting aqueous solution of organic acids - the waste of the process of oxidation of CG was subjected to esterification with alcohol. The esterification of the aqueous layer of acids in the excess of n-butanol in the presence of an ion exchange resin KU-2 was carried out at boiling point of the azeotropic water-n-butanol azeotrope $\mathrm{T}=365 \mathrm{~K}$.

After the esterification process, distillation of water and unreacted n-butanol was performed. The mass of the resulting mixture of esters is $\mathrm{m}$ (sums) = $=4.467 \mathrm{~g}$. An analysis of the composition of the resulting mixture of products was carried out, which is shown in the table (Table 4). The yield of esters is $\mathrm{n}=57.6 \%$.

For an approximate comparative estimation of the efficiency of using this complex method of oxidation products, we will convert the amount of products obtained into $1000 \mathrm{~kg}$ of the reacted $\mathrm{CH}$ and compare them with similar data obtained in the presence of individual NC, provided that the acids are neutralized and the adipates obtained are burned (Table 5, 6).

Thus, in the oxidation of $1 \mathrm{t}$ cyclohexane in the application of an industrial catalyst - NC, m (COL, CON, AA) was obtained $=863 \mathrm{~kg}$ of a mixture of $\mathrm{COL}, \mathrm{CON}$ and adipic acid, which was neutralized 
by the $\mathrm{m}(\mathrm{NaOH})=228 \mathrm{~kg}$ of sodium hydroxide (tab. 5). In the case of oxidation of $\mathrm{CH}$ in the presence of a binary catalytic system NC-CEE (1: 1) $\mathrm{m}=860 \mathrm{~kg}$ of the mixture of COL and CON, dibutyl adipinate $\mathrm{m}=727 \mathrm{~kg}$ and $\mathrm{m}=69 \mathrm{~kg}$ of adipates were obtained (Table 6). Comparing the obtained data, we can see that the amount of the resulting mixture of COL and CON in both cases is practically equal, however, in the presence of NC-CEE, we received more acids, which were used as raw material for obtaining additional amount of target products, namely dibutyl adipinate.

Table 4

Composition of received cube of esterification of adipic acid and $n$-butanole at $T=365 K$

\begin{tabular}{|c|c|c|c|c|}
\hline $\begin{array}{c}\mathrm{C}(\mathrm{AC}), \\
\mathrm{mol} / \mathrm{l}\end{array}$ & $\begin{array}{c}\mathrm{C}(\mathrm{HPCH}), \\
\mathrm{mol} / \mathrm{l}\end{array}$ & $\begin{array}{c}\mathrm{C}(\mathrm{DBA}), \\
\mathrm{mol} / \mathrm{l}\end{array}$ & $\begin{array}{c}\mathrm{C}(\mathrm{COL}), \\
\mathrm{mol} / \mathrm{l}\end{array}$ & $\begin{array}{c}\mathrm{C}(\mathrm{CON}), \\
\mathrm{mol} / \mathrm{l}\end{array}$ \\
\hline 0.090 & 0.000 & 0.668 & 0.000 & 0.000 \\
\hline
\end{tabular}

Table 5

Amount of obtained aim products from 1 ton of reacted cyclohexane in the presence of $\mathrm{NC}$

\begin{tabular}{|l|c|c|}
\hline \multicolumn{1}{|c|}{ Compound } & Used, kg & $\begin{array}{c}\text { Recieved, } \\
\mathrm{kg}\end{array}$ \\
\hline Cyclohexane & 1000 & - \\
\hline n-butanole & - & - \\
\hline Sodium hydroxide & 228 & - \\
\hline COL + CON & - & 863 \\
\hline Adipates & - & 462 \\
\hline Dibutyl adipate & - & - \\
\hline Sum of the aim prod. & - & 863 \\
\hline
\end{tabular}

Table 6

Amount of obtained aim products from 1 ton of reacted cyclohexane in the presence of catalytic system NC-CEE

\begin{tabular}{|l|c|c|}
\hline Compound & Used, kg & Recieved, kg \\
\hline Cyclohexane & 1000 & - \\
\hline n-butanole & 417 & - \\
\hline Sodium hydroxide & 31 & - \\
\hline COL + CON & - & 860 \\
\hline Adipates & - & 69 \\
\hline Dibutyl adipate & - & 727 \\
\hline Sum of the aim products * & - & 1587 \\
\hline
\end{tabular}

* Mixture COL, CON and dibutyl adipate.

\section{Conclusion}

The obtained results testify to the possibility of creating a non-waste technology for oxidation of cyclohexane by complex processing of by-products of the process - alcohol fraction and acid mixtures. The method of using the alcohol fraction as an effective additive to diesel fuels was studied. The method of using a mixture of acids obtained in the process of oxidation of cyclohexane for the esterification of them with butyl alcohol and the preparation of a valuable ester, dibutyl adipinate was studied.

\section{Literature}

1. Лудин А. М. Реутський В. В. Вплив спиртових відходів на якість моторних палив // Вісник НУ “ЛП". Хімія, технологія речовин $і$ їх застосування. 2007. № 590. С. 195-199. 


\title{
А. М. Лудин, В. В. Реутський, В. В. Реутський
}

2. O. Ivashchuk, V. Reutskyy, S. Mudryy, O. Zaichenko, N. Mitina Cyclohexane oxidation in the presence of variable valency metals chelates // Chemistry \& Chemical Technology. 2012. Vol. 6, No. 3. P. 339-343.

3. Белянин Б. В., Эрих В.Н. Технический анализ нефтепродуктов и газа.- Изд."Химия". Ленинград 1975. C. 66-169.

4. Christopher, R. Oxidation of Cyclohexane by Transition Metal Oxides on Zeolites / R. Christopher, R. Riley, E. Nancy Montgomery, N. Nada Megally, A. Jessica Gunn, L. Shannon Davis // The Open Catalysis Journal. 2012. Vol. 3. P. 8-13.1

5. Мельник С. Р., Мельник Ю. Р., Іващук О. С., Миговський М. Л., Реутський В. В. Одержання естерів 3 побічних продуктів виробництва адипінової кислоти // Вісник Начіонального університету "Львівська політехніка”. Хімія, технологія речовин та їх застосування. 2004. № 497. С. 88-90.

6. Мельник С. Р., Качмар-Кос Н. Я. Естерифікація адипінової кислоти. Вплив природи кислотних каталізаторів на процес // Хімічна промисловість Украӥни. 2008. № 1. С. 7-11.

7. Солод М. І., Мельник С. Р. Естерифікація адипінової кислоти спиртами $\mathrm{C}_{12}-\mathrm{C}_{14}$ // Вісник Національного університету “Львівська політехніка". Хімія, технологія речовин та їх застосування. 2009. № 644. С. 149-151.
8. Melnyk, S. Perfluorooxasulphonates of metals the catalysts of ester's manufacture // Chemistry \& Chemical Technology. 2013. Vol. 7, No. 9. P. 257-260.

9. Tracy Zhang, Bob Howell, Adina Dumitrascu, Steven J.Martin, Patrick B.Smith. Synthesis and characterization of glycerol-adipic acid hyperbranched polyester // Polymer. 2014. Vol. 55, No. 20. P.5065-5072

10. Gerhard Knothe, Robert Dunn. A Comprehensive Evaluation of the Melting Points of Fatty Acids and Esters Determined by Differential canning Calorimetry // Jornal of te American Oil Chemists Society. 2009. Vol. 86. No. 9. P. 843-856.

11. Gerhard Knothe. Improving Biodiesel Fuel Properties by Modifying Fatty Ester Composition.// Energy and Environmental Science. 2009. Vol. 9. No. 2. P. 759-766.

12. Lucie Coniglio, Hayet Hayet Bennadji, Pierre Alexandre Glaude, Olivier Herbinet, Francis Billaud. Combustion chemical kinetics of biodiesel and related compounds (methyl and ethyl esters): Experiments and modeling - Advances and future refinements. Progress in Energy and Combustion Science, 2013, 39, pp. 340-382.

13. Melnyk Yu., Starchevskyi R., Melnyk S. Transesterification of sunflower oil triglycerides by 1-butanol in the presence of d-metal oxides // Voprosy khimii $i$ khimicheskoi tekhnologii, 2019, No. 4, pp. 95-10.

\author{
А. М. Лудин, В. В. Реутський, В. В. Реутський \\ Національний університет “Львівська політехніка", \\ кафедра технології органічних продуктів \\ anatolii.m.ludyn@1pnu.ua
}

\section{СТВОРЕННЯ ОСНОВ БЕЗВІДХОДНОЇ ТЕХНОЛОГІЇ ОКИСНЕННЯ ЦИКЛОГЕКСАНУ}

Запропоновано основи комплексної переробки і створення безвідходної технології процесу окиснення циклогексану. Розглянуто методи використання побічних продуктів процесу окиснення циклогексану - спиртової фракції та суміші кислот. Вивчено метод використання спиртової фракції як ефективної добавки до дизельних палив. Досліджено, що добавки спиртової фракції покращують технологічні та експлуатаційні властивості дизельних палив. Вивчено метод використання суміші кислот, що одержують в процесі окиснення циклогексану, для естерифікації їх із бутиловим спиртом та одержання цінного естеру - дибутиладипінату.

Ключові слова: окиснення, циклогексан, спиртова фракція, адипінова кислота, етерифікація, естер, дизельне паливо. 